\title{
Performance, serum biochemical indices and crude protein utilization by broiler chickens fed diets based on two varieties of cassava (Manihot esculenta Crantz) grits II. Finisher Phase
}

Ogunwole $^{1}$, O. A., Abayomi ${ }^{1}$, F. D., Oladimeji ${ }^{1}$, S. O., Olumide ${ }^{2}$, M. D., Lawal $^{1}$, H. O., Idowu', A. I., Mosuro ${ }^{1}$, A. O., Kulakow ${ }^{3}$, P. O., Iluebbey ${ }^{3}$, P. and Tewe', O. O.

${ }^{1}$ Agricultural Biochemistry and Nutrition Unit, Department of Animal Science, University of Ibadan, Ibadan, Nigeria

${ }^{2}$ Department of Animal Science, School of Agriculture and Industrial Technology,

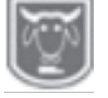

Abstract

Babcock University, Ilishan Remo, Ogun State. Nigeria

${ }^{3}$ International Institute of Tropical Agriculture (IITA), Ibadan, Nigeria

E-mail of corresponding author: droaogunwole@gmail.com $+2348033939829$

Effects offeeding diets based on grits from two varieties of cassava on performance, selected serum biochemical indices and crude protein utilization by broiler finisher chickens was studied. In a completely randomized design, Abor Acre broiler chickens $(n=210)$ aged 21 days were allotted to seven dietary treatments; each replicated thrice comprising 10 birds per replicate. Seven isocaloric and isonitrogenous diets were formulated; diet 1 contained 50 $\%$ maize and $0 \%$ cassava grits while diets 2, 3 and 4 had 25, 50 and 75\% of maize replaced, respectively with cassava grits from TMS 01/1371, diets 5, 6 and 7 had their maize replaced with cassava grits from TME 419 at 25, 50 and 75\%, respectively. Chickens were fed on respective experimental diets and offered water ad libitum for three weeks. Feed intake, weight gain, feed and conversion ratio $(F C R)$ differed significantly $(P<0.05)$ while metabolizable crude protein (MCP) values were similar $(P>0.05)$. Higher daily weight gain (DWG) was obtained in birds on diet 7 (69.56 g), 1 (62.71) and 4 (60.25) compared with those on diets 6 (58.10), 3 (54.76), 2 (52.02) and 5 (50.07). Serum albumin (g/dL) were lower but similar in birds on diets 2 (2.35), 3 (2.03), 4(1.97) 5 (1.98). Globulin values varied significantly $(P<0.05)$ across treatments. There was however, no significant effect of treatments $(P<0.05)$ on total protein, aspartate amino transferase, alanine amino transferase, serum urea nitrogen and creatinine. Interactions of grit varieties and increased dietary inclusion levels of TMS 01/1371 reduced metabolizable crude protein of finishers' broiler significantly $(P<0.05)$. This relationship was not significant for TME $419(P>0.05)$. Dietary cassava grits from both varieties of cassava had no deleterious effect on overall broiler chickens performance. However, there was gross reduction in metabolizable crude protein with increasing dietary inclusion of cassava grits.

Keywords: Broiler performance, Serum biochemical indices, Cassava grits, $\beta$-carotene cassava, Metabolizable crude protein

\section{Introduction}

A perfect understanding of associations among dietary components of broiler chicken is of main significance in profitable broiler production (Ferket and Gernat, 2006). Broiler chickens rations are formulated to supply all the macro and micro nutrients with relatively more emphasis among others on crude protein due to its role in the generation of muscles and health of birds. Crude protein also has marked effect on performance and overall cost of finished products (Firman and Boling, 1998). The focus of the poultry farmers is on producing birds at minimal cost and maximum profit. Authors (Fajimi et al., 1993; Tewe, 1997) observed that 60$80 \%$ of the total costs of producing 
livestock, especially, poultry in Nigeria are directly related to feeding. The costs of feeding have continued to rise due to continuous increase in the price of feedstuff which includes maize.

Maize is the main ingredients in the feed of broiler chicken; it constitutes $50-70 \%$ of broiler rations. Inadequacy and unsteady production of maize coupled with intense competition for maize between humans and stocks has led researchers to vigorous search for alternative energy sources such as cassava. Cassava products such as fermented cassava peel, cassava peel meal, cassava waste and cassava root-leaf meal mixture (Ofuya and Obilor, 1993; Apata et al., 1999; Salami and Odunsi, 2003; Ngiki et al., 2014) have been used in the feeding broiler chickens. Recently developed biofortified varieties of cassava (IITA, 2011) which include TMS 01/1371, TMS $01 / 1368$ and TMS 01/1412 are yet to be extensively evaluated in poultry production.

Beside, cassava and maize are predominantly made of starch (Weurding et al., 2003; Anton et al., 2009; Okudoh et al., 2014) and are incorporated into poultry diet as native starch. The differences in the digestive characteristics of the two native products in animals arose primarily from the varying proportions of amylose to amylopectin which reportedly altered the relative passage rate and eventual breakdown in the gastro intestinal tracts (Weurding et al., 2001; Adeleye et al., 2016). The dynamics of different starch digestion was due to their differential capability in eliciting metabolic responses in the animal, particularly, in synchronization of protein and starch digestion effects on insulin and microbial responses. Despite the envisaged varying dietary effects of these native starches on crude protein digestion and utilization by the animals, little or no emphasis has been deployed to document them.

This study was aimed at assessing the effects of feeding grits $b$ ased diets from two varieties of cassava (Manihot esculenta Crantz) on performance, serum biochemical indices and crude protein utilization by broiler finisher chickens

\section{Materials and Methods Experimental Site}

The experiment was carried out at the Poultry Unit, Teaching and Research Farm, University of Ibadan, Ibadan, Nigeria located on latitude $7^{0} 20^{1} \mathrm{~N}$, longitude $3^{0}$ $50^{1} \mathrm{E}$, and $200 \mathrm{~m}$ above sea level, in tropical rain forest vegetation zone. The laboratory analyses were carried out at the Department of Animal Science, University of Ibadan, Ibadan.

\section{Test Materials}

Tubers from cassava varieties TME 419 and TMS $01 / 1371$ at 12 months of age were obtained from the International Institute of Tropical Agriculture, Ibadan, Nigeria. Cassava grits was processed from cassava tuber of TME 419, the conventional variety and TMS 01/1371 notable for $\beta$-carotene using the method of Tewe (2005).

\section{Experimental Diets}

Seven iso-nitrogenous and iso-caloric diets were formulated for finisher broiler chickens. Details of dietary composition for finisher broiler chickens have been documented (Ogunwole et al., 2016a, b) and are shown in Table 1. Finisher diets were offered from day 22 to 42 . Diet 1 was a maize-soya diet which contained $52 \%$ maize ( $0 \%$ cassava grit), diets 2,3 and 4 had their maize replaced with grits from TMS $01 / 1371$ at 25,50 and $75 \%$, respectively while diets 5, 6 and 7 had maize similarly replaced with TME 419 grit at 25, 50 and $75 \%$, respectively.

\section{Experimental Animal}

Arbor Acre broiler chickens $(n=210)$ from Siebrier Hatchery, Awe, Nigeria, were 
randomly allotted to seven dietary treatments. Each treatment was in triplicate of ten broilers per replicate. Birds were raised in a deep litter house with separate feeder and water trough. Feed and water were given ad libitum.

\section{Performance Characteristics}

The trial started at day 22 till day 42 of the birds; during the period feed consumptions were quantified on daily basis. The chicks were weighed at the start of the experiment and subsequently on weekly basis. Parameters measured and calculated were weight gain, feed intake, feed conversion ratio.

\section{Serum Collection and Analysis}

At day 21, blood was collected from six chicks per treatment for the laboratory determination of serum biochemical indices; collection was by jugular vein puncture of the chicks using needles and syringes. Approximately $3 \mathrm{~mL}$ of blood was drawn into properly tilted sterile blood tubes without anticoagulant and the serum harvested. Total serum protein was by Biuret method as described by Reinhold (1953). Serum albumin was determined using bromocresol green method (Peter et al., 1982). Globulin was calculated by subtraction of albumin from total serum protein while albumin/globulin ratio was calculated by dividing albumin by the globulin value. Serum creatinine and urea nitrogen were determined with the method of Toro and Ackermann (1975). Alkaline phosphatase (ALP), aspartate amino transferase (AST) and alanine amino transferase (ALT) were determined spectrophotometrically as described (Reitman and Frankel, 1957).

Table 1: Gross composition (g/100g DM) of the experimental finisher diet

\begin{tabular}{|c|c|c|c|c|c|c|c|c|c|c|c|}
\hline \multirow[b]{3}{*}{ Ingredient } & \multicolumn{10}{|c|}{ Inclusion levels of cassava grits (\%) } & \multirow[b]{3}{*}{$\begin{array}{l}\text { Diet7 } \\
75\end{array}$} \\
\hline & \multirow{2}{*}{\multicolumn{2}{|c|}{$\begin{array}{l}\text { Diet } 1 \text { control } \\
\text { (0) }\end{array}$}} & \multicolumn{4}{|c|}{ TMS 01/1371 } & \multirow{2}{*}{\multicolumn{2}{|c|}{$\begin{array}{l}\text { Diet } 4 \\
75\end{array}$}} & \multicolumn{2}{|c|}{ TME 419} & \\
\hline & & & \multicolumn{2}{|c|}{$\begin{array}{l}\text { Diet } 2 \\
25\end{array}$} & \multicolumn{2}{|c|}{$\begin{array}{l}\text { Diet } 3 \\
50\end{array}$} & & & $\begin{array}{l}\text { Diet5 } \\
25 \\
\end{array}$ & $\begin{array}{l}\text { Diet6 } \\
50 \\
\end{array}$ & \\
\hline Maize & 52.00 & & \multicolumn{2}{|c|}{39.00} & \multicolumn{2}{|c|}{26.00} & \multicolumn{2}{|l|}{13.00} & 39.00 & 26.00 & 13.00 \\
\hline TME 419 & 0.00 & & \multicolumn{2}{|c|}{0.00} & \multicolumn{2}{|c|}{0.00} & \multicolumn{2}{|l|}{0.00} & 13.00 & 26.00 & 39.00 \\
\hline TMS 01/1371 & 0.00 & & \multicolumn{2}{|c|}{13.00} & \multicolumn{2}{|c|}{26.00} & \multicolumn{2}{|l|}{39.00} & 0.00 & 0.00 & 0.00 \\
\hline Soybean meal $(42 \% \mathrm{CP})$ & 30.90 & & \multicolumn{2}{|c|}{34.00} & \multicolumn{2}{|c|}{36.50} & \multicolumn{2}{|l|}{39.90} & 33.50 & 36.90 & 39.50 \\
\hline wheat offal & 11.34 & & \multicolumn{2}{|c|}{8.24} & \multicolumn{2}{|c|}{5.74} & \multicolumn{2}{|l|}{2.34} & 8.74 & 5.34 & 2.74 \\
\hline DL-Methionine & 0.20 & & \multicolumn{2}{|c|}{0.20} & \multicolumn{2}{|c|}{0.20} & \multicolumn{2}{|l|}{0.20} & 0.20 & 0.20 & 0.20 \\
\hline L-lysine & 0.10 & & \multicolumn{2}{|c|}{0.10} & \multicolumn{2}{|c|}{0.10} & \multicolumn{2}{|l|}{0.10} & 0.10 & 0.10 & 0.10 \\
\hline Oyster shell & 1.00 & & 1.0 & & 1.0 & & 1.00 & & 1.00 & 1.00 & 1.00 \\
\hline Palm oil & 2.40 & & 2.4 & & 2.4 & & 2.40 & & 2.40 & 2.40 & 2.40 \\
\hline Dicalcium phosphate & 1.50 & & 1.5 & & 1.5 & & 1.50 & & 1.50 & 1.50 & 1.50 \\
\hline Premix & 0.25 & & 0.2 & & 0.2 & & 0.25 & & 0.25 & 0.25 & 0.25 \\
\hline Salt & 0.25 & & 0.2 & & 0.2 & & 0.25 & & 0.25 & 0.25 & 0.25 \\
\hline Avatec & 0.06 & & 0.0 & & 0.0 & & 0.06 & & 0.06 & 0.06 & 0.06 \\
\hline Total & 100.00 & & 100 & .00 & 100 & .00 & 100.0 & & 100.00 & 100.00 & 100.00 \\
\hline Calculated Nutrients Cor & position & & & & & & & & & & \\
\hline $\mathrm{ME}(\mathrm{Kcal} / \mathrm{kg})$ & 3062.44 & 308 & 2.45 & 309 & 7.48 & & 9.98 & & & 3087.80 & 3097.16 \\
\hline Crude protein $(\%)$ & 19.58 & 19. & & 19. & & 19 & & 19 & & 19.30 & 19.06 \\
\hline Methionine (\%) & 0.50 & 0.5 & & 0.4 & & 0.4 & & 0.4 & & 0.49 & 0.48 \\
\hline Lysine $(\%)$ & 1.19 & 1.2 & & 1.2 & & 1.2 & & 1.2 & & 1.26 & 1.28 \\
\hline Available phosphorus (\%) & 0.51 & 0.5 & & 0.5 & & 0.5 & & 0.5 & & 0.50 & 0.50 \\
\hline Calcium $(\%)$ & 0.82 & 0.8 & & 0.8 & & 0.9 & & 0.8 & & 0.87 & 0.90 \\
\hline Price $(\mathrm{N})$ & 92.80 & 90 . & & 87. & & 85 & & 89 & & 87.66 & 84.83 \\
\hline
\end{tabular}

M.E: Metabolizable Energy

Each $1.25 \mathrm{~kg}$ vitamin/mineral premix contain: vitamin A $\quad-10,0000,0000$ I.U, vitamin D 3-22000000 I.U., vitamin E-10,000mg, vitamin $K_{3}-2,000$, Folic Acid-500mg, Niacin-15,000mg, Calpan-5000mg, vitamin $B_{2-}$ 5,000mg, vitamin B12 -10mg, vitamin B1 -1500mg, vitamin B6 -1500mg, Biotin -20mg, antioxidant 125,000mg, selenium -200mg, iodine -1000mg, iron -40,000mg, cobalt 200mg, manganese -70,000mg, copper-4000mg, Zinc-50,000mg, choline chloride 150,000mg and yolk colorant. 
Performance, serum biochemical indices and crude protein utilisation by broiler chickens fed two varieties of cassava grits

Metabolizable crude protein determination

At week 6, two birds per replicate were moved to the metabolic cage for crude protein digestibility determination. Birds were allowed to adjust for a period of three days before then subsequent collection of feacal samples for three days. Faeces were allowed to drop into 3\% sulphuric acid, collected at 24 hours intervals, then were oven dried at $105{ }^{\circ} \mathrm{C}$ for 48 hours. Metabolizable Crude Protein (MCP) was obtained using the equation:

$\mathrm{MCP}=$

Ingested crude protein-excreted crude protein X 100

\section{Statistical analysis}

Data were subjected to analysis of variance using SAS (2002). Means were separated using Duncan option of the same software Ingested crude protein

\section{Statistical analysis}

Data were subjected to analysis of variance using SAS (2002) Means were separated using Duncan option of the same software $\alpha_{0.05}$.

\section{Results}

Effects of cassava grits from two varieties of cassava on performance and MCP of broiler chickens at the finisher phase is shown in Table 2. There were significant differences $(\mathrm{P}<0.05)$ in the final weight (FWT), Daily feed intake per birds (DFI/birds), daily weight gain (DWG /birds), FCR and daily crude protein intake (DCPI). There was however no significant difference $(\mathrm{P}>0.05)$ in MCP. Birds on diet 1 had higher $(\mathrm{P}<0.05)$ final weight $(2091 \mathrm{~g})$ and DFI (164.62g) compared with lower 1750.6 and $139.80 \mathrm{~g}$, respectively by birds on diet 7 . Higher DWG was recorded by birds on diet 5 (50.07). Birds on diet 5 had higher $(\mathrm{P}<0.05)$ FCR $(3.18)$ and lower FCR (2.02) by birds on diet 7 . Birds on diet 5 recorded higher MCP (67.05\%) compared with those on diet $7(55.46 \%)$. Birds on diet 2 recorded higher $(\mathrm{P}<0.05)$ DCPI $(29.49 \mathrm{~g})$ compared with those on diet 5 (26.70).

Table 2: The effects of cassava grits from two varieties of cassava on performance and metabolizable crude protein of broiler chickens at finisher phase

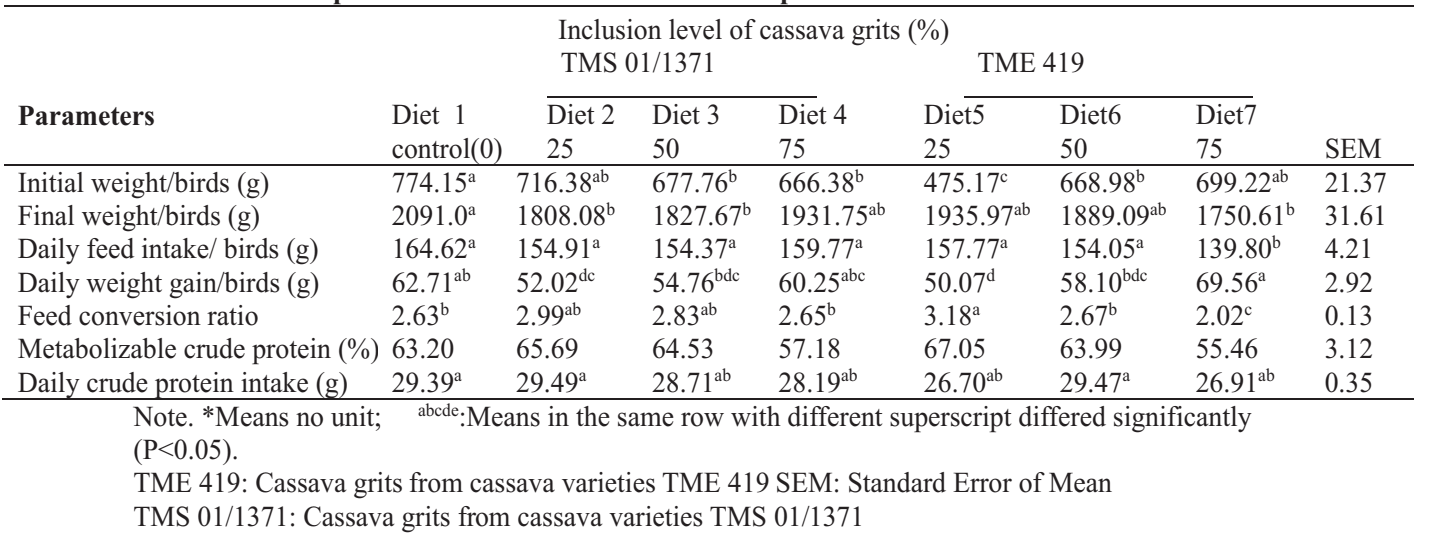

Main effect of cassava grits varieties and inclusion level on performance of broiler finisher chickens is shown in Table 3. There were no significant differences $(\mathrm{P}>0.05)$ in the main effect of cassava grit varieties on FWT, DFI, DWG, FCR and MCP.
Significant differences $(\mathrm{P}<0.05)$ were recorded in DFI, FCR and MCP due to main effect of inclusion. No significant difference $(\mathrm{P}>0.05)$ was recorded in the main effect of inclusion levels on DWG of birds and DCPI. 
Ogunwole, Abayomi, Oladimeji, Olumide, Lawal, Idowu, Mosuro, Kulakow, Iluebbey and Tewe

Table 3: The main effect of cassava grits varieties and inclusion levels on performance of broiler chickens at finisher phase

\begin{tabular}{|c|c|c|c|c|c|c|c|}
\hline \multirow[b]{2}{*}{ Parameters } & \multicolumn{2}{|c|}{ Grits varieties } & \multicolumn{4}{|c|}{ Level of Inclusion } & \multirow[b]{2}{*}{ SEM } \\
\hline & $\begin{array}{l}\text { TMS } \\
01 / 1371\end{array}$ & TME 419 & SEM & 25 & 50 & 75 & \\
\hline Initial weight/birds(g) & $686.91 \mathrm{a}$ & $614.46 \mathrm{~b}$ & 18.30 & $682.90^{\mathrm{a}}$ & $673.37^{\mathrm{a}}$ & $595.77^{\mathrm{b}}$ & 22.41 \\
\hline Final weight/birds(g) & 1856.1 & 1858.6 & 41.18 & 1841.2 & 1858.4 & 1872.4 & 50.44 \\
\hline Daily feed intake/ birds (g) & 156.35 & 150.54 & 2.63 & $158.77^{\mathrm{a}}$ & $154.21^{\mathrm{ab}}$ & $147.36^{\mathrm{b}}$ & 3.22 \\
\hline Daily weight gain/birds (g) & 55.68 & 59.24 & 1.77 & 55.16 & 56.43 & 60.79 & 2.17 \\
\hline Feed conversion ratio & 2.82 & 2.62 & 0.08 & $2.92^{\mathrm{a}}$ & $2.75^{\mathrm{ab}}$ & $2.50^{\mathrm{b}}$ & 0.10 \\
\hline Metabolizable crude protein $(\%$ & o, 62.47 & 62.17 & 2.23 & $66.37^{\mathrm{a}}$ & $64.26^{\mathrm{ab}}$ & $56.32^{\mathrm{b}}$ & 2.73 \\
\hline Daily crude protein intake (g) & 28.80 & 27.69 & 0.48 & 28.09 & 29.09 & 27.55 & 0.59 \\
\hline
\end{tabular}

Note. *Means no unit ; abcde:Means in the same row with different superscript differed significantly $(\mathrm{P}<0.05)$.

TME 419: Cassava grits from cassava varieties TME 419 SEM: Standard Error of Mean

TMS 01/1371: Cassava grits from cassava varieties TMS 01/1371

Effect of interaction of grits from two cassava varieties and inclusion levels on performance of finisher broiler is shown in Table 4. There were significant differences $(\mathrm{P}<0.05)$ in the DFI, DWG and FCR of birds fed various diets. There was no significant difference $(\mathrm{P}>0.05)$ in the MCP and DCPI of birds fed various diets. The highest DFI, DWG and FCR were recorded in birds on diet with $25 \%$ inclusion of TMS 01/1371 (159.77g), $75 \%$ inclusion of TME 419 (69.56) and 25\% inclusion of TME 419 (3.18), respectively. Corresponding lower
DFI, DWG and FCR were recorded by broilers on $75 \%$ TME 419 inclusion (139.80g), 25\% inclusion of TME 419 $(50.07 \mathrm{~g})$ and $75 \%$ inclusion of TME 419 (2.02). The highest MCP was recorded by birds on $25 \%$ TME 419 inclusion $(67.05 \%)$ and least MCP recorded by birds on $75 \%$ TMS 01/1371 (57.18\%) diet. Higher DCPI was obtained from birds on $25 \%$ dietary TMS 01/1371 inclusion $(29.49 \mathrm{~g})$ and the lower DCPI by birds on $25 \%$ inclusion of TME $419(26.70 \mathrm{~g})$

Table 4: The interaction effects of grits from two cassava varieties and inclusion levels on performance of Finisher Phase

\begin{tabular}{|c|c|c|c|c|c|c|c|}
\hline \multirow[b]{2}{*}{ Parameters } & \multicolumn{6}{|c|}{$\begin{array}{c}\text { Inclusion level of cassava grits }(\%) \\
\text { TMS } 01 / 1371\end{array}$} & \multirow[b]{2}{*}{ SEM } \\
\hline & 25 & 50 & 75 & 25 & 50 & 75 & \\
\hline Initial weight/birds(g) & $716.38^{\mathrm{ab}}$ & $677.76^{\mathrm{b}}$ & $666.58^{\mathrm{b}}$ & $475.17^{\mathrm{c}}$ & $668.98^{b}$ & $699.22^{\mathrm{ab}}$ & 31.70 \\
\hline Final weight/birds $(\mathrm{g})$ & 1808.9 & 1827.7 & 1931.75 & 1935.75 & 1889.1 & 1750.61 & 71.33 \\
\hline Daily feed intake/ birds (g) & $159.77^{\mathrm{a}}$ & $154.37^{\mathrm{a}}$ & $154.91^{\mathrm{a}}$ & $157.77^{\mathrm{a}}$ & $154.05^{\mathrm{a}}$ & $139.80^{b}$ & 4.55 \\
\hline Daily weight gain/birds (g) & $60.25^{\mathrm{ab}}$ & $54.76^{\mathrm{bc}}$ & $52.02^{\mathrm{bc}}$ & $50.07^{\mathrm{c}}$ & $58.10^{\mathrm{bc}}$ & $69.56^{\mathrm{a}}$ & 3.07 \\
\hline Feed conversion ratio & $2.65^{b}$ & $2.83^{\mathrm{ab}}$ & $2.99^{\mathrm{ab}}$ & $3.18^{\mathrm{a}}$ & $2.67^{b}$ & $2.02^{\mathrm{c}}$ & 0.13 \\
\hline Metabolizable crude protein $(\%)$ & 65.69 & 64.53 & 57.18 & 67.05 & 63.99 & 55.46 & 3.86 \\
\hline Daily crude protein intake $(\mathrm{g})$ & 29.49 & 28.71 & 28.19 & 26.70 & 29.47 & 26.91 & 0.83 \\
\hline
\end{tabular}

Note. *Means no unit; $\quad$ abcde:Means in the same row with different superscript differed significantly $(\mathrm{P}<0.05)$.

TME 419: Cassava grits from cassava varieties TME $419 \quad$ SEM: Standard Error of Mean

TMS 01/1371: Cassava grits from cassava varieties TMS 01/1371 
Performance, serum biochemical indices and crude protein utilisation by broiler chickens fed two varieties of cassava grits

Serum biochemical indices of broiler finisher fed various inclusion level of cassava grits is shown in Table 5. There were no significant differences $(\mathrm{P}>0.05)$ in total protein, aspartate amino transferase (AST), alanine amino transferase (ALT), serum urea nitrogen (SUN) and creatinine. Albumin, globulin, albumin/globulin ratio (A/G ratio) and alkaline phosphatase (ALP) differed significantly $(\mathrm{P}<0.05)$.

Birds on diet 2 recorded the higher $(\mathrm{P}<0.05)$ albumin $(2.35 \mathrm{~g} / \mathrm{dL}), \mathrm{A} / \mathrm{G}$ ratio (1.55), AST
$(257.83 \mu \mathrm{L})$ and ALP $(74.00 \mu \mathrm{L})$. Birds on diets 5, 7 and 3 had lower albumin (1.67 $\mathrm{g} / \mathrm{dL}), \mathrm{A} / \mathrm{G}$ ratio $(0.80)$, AST $(222.00 \mu \mathrm{L})$ and ALP $(61.83 \mu \mathrm{L})$, respectively. Birds on diet 3 had higher serum total protein $(4.30$ $\mathrm{g} / \mathrm{dL}$ ) while lower value was recorded by birds on diet $7(3.880 \mathrm{~g} / \mathrm{dL})$. Birds on diet 2 recorded lower globulin $(1.55 \mathrm{~g} / \mathrm{dL})$ and ALT $(31.67 \mu \mathrm{L})$. Higher serum globulin $(2.13 \mathrm{~g} / \mathrm{dL})$ was recorded by birds on diet 7 while higher ALT $(36.17 \mu \mathrm{L})$ was in serum of birds fed diet 5 .

Table 5: Serum biochemical indices of broiler finisher chickens fed various inclusion level of cassava grits at finisher phase

\begin{tabular}{|c|c|c|c|c|c|c|c|c|}
\hline \multirow[b]{3}{*}{ Parameters } & \multicolumn{7}{|c|}{ Inclusion level of cassava grits (\%) } & \multirow[b]{3}{*}{ SEM } \\
\hline & \multirow[b]{2}{*}{0} & \multicolumn{3}{|c|}{ TMS 01/1371 } & \multicolumn{3}{|c|}{ TME 419} & \\
\hline & & 25 & 50 & 75 & 25 & 50 & $75 \%$ & \\
\hline Total protein $\mathrm{g} / \mathrm{dL}$ & 3.97 & 4.07 & 4.30 & 3.98 & 4.12 & 4.02 & 3.88 & 0.23 \\
\hline Albumin $\mathrm{g} / \mathrm{dL}$ & $1.82^{\mathrm{b}}$ & $2.35^{\mathrm{a}}$ & $2.03^{\mathrm{ab}}$ & $1.97^{\mathrm{ab}}$ & $1.98^{\mathrm{ab}}$ & $1.67^{\mathrm{b}}$ & $1.75^{\mathrm{b}}$ & 0.23 \\
\hline Globulin g/dL & $1.82^{\mathrm{ab}}$ & $1.55^{\mathrm{b}}$ & $1.93^{\mathrm{ab}}$ & $2.02^{\mathrm{a}}$ & $1.90^{\mathrm{ab}}$ & $1.85^{\mathrm{ab}}$ & $2.13^{\mathrm{a}}$ & 0.20 \\
\hline *Albumin/Globulin ratio & $1.00^{\mathrm{b}}$ & $1.55^{\mathrm{a}}$ & $1.03^{\mathrm{b}}$ & $0.97^{\mathrm{b}}$ & $1.10^{\mathrm{b}}$ & $0.88^{\mathrm{b}}$ & $0.80^{\mathrm{b}}$ & 0.19 \\
\hline Alanine amino transferase $(\mu \mathrm{L})$ & 239.00 & 257.83 & 222.00 & 246.67 & 252.33 & 257.67 & 247.00 & 19.77 \\
\hline Aspatate amino transferase $(\mu \mathrm{L})$ & 32.33 & 31.67 & 32.33 & 31.83 & 36.17 & 34.50 & 33.83 & 3.37 \\
\hline Alkaline phosphatase $(\mu \mathrm{L})$ & $65.17^{\mathrm{ab}}$ & $74.00^{\mathrm{a}}$ & $61.83^{\mathrm{b}}$ & $66.50^{\mathrm{ab}}$ & $69.67^{\mathrm{ab}}$ & $71.00^{\mathrm{ab}}$ & $62.50^{\mathrm{ab}}$ & 5.23 \\
\hline Serum urea nitrogen $(\mathrm{mg} / \mathrm{dL})$ & 1.00 & 1.20 & 1.23 & 1.12 & 1.12 & 1.20 & 1.12 & 0.10 \\
\hline Creatinine $(\mathrm{mg} / \mathrm{dL})$ & 0.93 & 1.02 & 1.07 & 1.10 & 1.02 & 1.05 & 1.10 & 0.09 \\
\hline
\end{tabular}

Table 6 shows the main effect of cassava grits varieties and inclusion levels on serum biochemical indices of broiler chickens at the finishers' phase. The main effect of cassava grits varieties on total protein, globulin, AST, ALT, ALP, SUN and creatinine were not significantly different $(\mathrm{P}>0.05)$. Albumin and $\mathrm{A} / \mathrm{G}$ of birds were however, significantly influenced $(\mathrm{P}<0.05)$ by the varieties of dietary cassava grit. Birds on TMS 01/1371 recorded the higher albumin $(2.12 \mathrm{~g} / \mathrm{dL})$ and $\mathrm{A} / \mathrm{G}$ ratio (1.18) while lower albumin $(1.80 \mathrm{~g} / \mathrm{dL})$ and $\mathrm{A} / \mathrm{G}$ ratio (0.93) were recorded in birds on TME 419. Birds fed two varieties of cassava grits recorded similar levels of creatinine.

Main effect of inclusion levels of cassava grit on total protein, albumin, AST, ALT,
SUN and creatinine of birds were not significantly different $(\mathrm{P}>0.05)$. The influence of grit types on globulin, and ALP was not significant $(\mathrm{P}>0.05)$. Higher albumin $(2.17 \mathrm{~g} / \mathrm{dL}), \mathrm{A} / \mathrm{G}$ ratio (1.33), and ALP $(71.83 \mu \mathrm{L})$ were recorded in birds on $25 \%$ inclusion level of cassava grits. Lower albumin $(1.85 \mathrm{~g} / \mathrm{dL}), \mathrm{A} / \mathrm{G}$ ratio $(0.88)$ and $\operatorname{ALP}(64.50 \mu \mathrm{L})$ were recorded in chickens on $50,75,50,50$ and $75 \%$ dietary cassava grit inclusions, respectively.

Total protein and SUN of birds on different diets were not significantly different $(\mathrm{P}>0.05)$. However, albumin ( $\mathrm{g} / \mathrm{dL})(2.12)$ was higher $(\mathrm{P}<0.05)$ in serum of birds fed TMS 01/137 compared with those TME 419 (1.08) while serum globulin tended to increase with inclusion levels of cassava. 
Ogunwole, Abayomi, Oladimeji, Olumide, Lawal, Idowu, Mosuro, Kulakow, Iluebbey and Tewe

Table 6: Main effect of cassava grits varieties and inclusion levels of cassava grits on serum biochemical indices of broiler chickens at finisher phase

\begin{tabular}{|c|c|c|c|c|c|c|c|}
\hline \multirow[b]{2}{*}{ Parameters } & \multicolumn{3}{|c|}{$\begin{array}{c}\text { Grits varieties } \\
\text { Level of Inclusion ( } \%)\end{array}$} & \multirow[b]{2}{*}{25} & \multirow[b]{2}{*}{50} & \multirow[b]{2}{*}{$75 \%$} & \multirow[t]{2}{*}{ SEM } \\
\hline & $\begin{array}{l}\text { TMS } \\
01 / 1371\end{array}$ & $\begin{array}{l}\text { TME } \\
419 \\
\end{array}$ & SEM & & & & \\
\hline Total Protein $(\mathrm{g} / \mathrm{dL})$ & 4.12 & 4.01 & 0.09 & 4.09 & 4.16 & 3.93 & 0.11 \\
\hline Albumin $(\mathrm{g} / \mathrm{dL})$ & $2.12^{\mathrm{a}}$ & $1.80^{\mathrm{b}}$ & 0.09 & 2.17 & 1.85 & 1.86 & 0.11 \\
\hline Globulin (g/dL) & 1.83 & 1.96 & 0.08 & $1.73^{b}$ & $1.89^{\mathrm{ab}}$ & $2.08^{\mathrm{a}}$ & 0.10 \\
\hline Albumin:Globulin ratio & $1.18^{\mathrm{a}}$ & $0.93^{b}$ & 0.08 & $1.33^{\mathrm{a}}$ & $0.96^{\mathrm{b}}$ & $0.88^{b}$ & 0.10 \\
\hline Aspartate amino transferase $\mu \mathrm{L}$ & 242.17 & 252.33 & 7.93 & 255.08 & 239.83 & 246.83 & 9.71 \\
\hline Alanine amino transferase $\mu \mathrm{L}$ & 31.94 & 34.83 & 1.37 & 33.92 & 33.42 & 32.83 & 1.68 \\
\hline Alkaline Phosphatase $\mu \mathrm{L}$ & 67.44 & 67.72 & 2.03 & $71.83^{\mathrm{a}}$ & $66.42^{\mathrm{ab}}$ & $64.50^{\mathrm{b}}$ & 2.49 \\
\hline Serum urea nitrogen $(\mathrm{mg} / \mathrm{dL})$ & 1.18 & 1.14 & 0.03 & 1.16 & 1.22 & 1.12 & 0.04 \\
\hline Creatinine $(\mathrm{mg} / \mathrm{dL})$ & 1.06 & 1.06 & 0.03 & 1.02 & 1.06 & 1.10 & 0.04 \\
\hline \multicolumn{8}{|c|}{$\begin{array}{l}\text { Note. *Means no unit; abcde:Means in the same row with different superscript differed sig1 } \\
(\mathrm{P}<0.05) \text {. } \\
\text { TME 419: Cassava grits from cassava varieties TME } 419 \text { SEM: Standard Error of Mean } \\
\text { TMS 01/1371: Cassava grits from cassava varieties TMS 01/1371 }\end{array}$} \\
\hline \multicolumn{3}{|c|}{$\begin{array}{l}\text { Interaction of effect of cassava grits } \\
\text { varieties and levels of inclusion on serum } \\
\text { biochemical indices of broiler chicken at the } \\
\text { finishers' phase are shown in Table } 7 \text {. There } \\
\text { were no significant differences }(\mathrm{P}>0.05) \text { in } \\
\text { the total protein, AST, ALT, SUN and } \\
\text { Creatinine of birds due to treatments. } \\
\text { However, significant variations }(\mathrm{P}<0.05)\end{array}$} & \multicolumn{5}{|c|}{$\begin{array}{l}\text { occurred in the values of albumin, Globulin, } \\
\mathrm{A} / \mathrm{G} \text { ratio and ALP of birds fed various diet. } \\
\text { Birds on diet } 2 \text { had higher albumin } \\
(2.35 \mathrm{~g} / \mathrm{dL}) \text {, A/G ratio }(1.55) \text { and ALP } \\
(74.00 \mu \mathrm{L}) \text { while lower albumin }(1.67 \mathrm{~g} / \mathrm{dL}) \text {, } \\
\mathrm{A} / \mathrm{G} \text { ratio }(0.80) \text { and ALP }(61.83 \mu \mathrm{L}) \text { were } \\
\text { recorded in birds on diets } 6,7,3 \text { and } 4 \text {, } \\
\text { respectively. }\end{array}$} \\
\hline \multicolumn{8}{|c|}{$\begin{array}{l}\text { Table 7: The interaction effect of cassava grits varieties and inclusion levels on serum biochemical } \\
\text { indices of broiler starters. }\end{array}$} \\
\hline \multicolumn{8}{|c|}{ Inclusion level of cassava grits $(\%)$} \\
\hline Parameters & 25 & 50 & 75 & $25^{-}$ & 50 & 75 & SEM \\
\hline Total Protein $(\mathrm{g} / \mathrm{dL})$ & 4.07 & 4.30 & 3.98 & 4.12 & 4.02 & 3.88 & 0.16 \\
\hline Albumin $(\mathrm{g} / \mathrm{dL})$ & $2.35^{\mathrm{a}}$ & $2.03^{\mathrm{ab}}$ & $1.97^{\mathrm{ab}}$ & $1.98^{\mathrm{ab}}$ & $1.67^{\mathrm{b}}$ & $1.75^{\mathrm{b}}$ & 0.16 \\
\hline Globulin $(\mathrm{g} / \mathrm{dL})$ & $1.55^{\mathrm{b}}$ & $1.93^{\mathrm{ab}}$ & $2.02^{\mathrm{a}}$ & $1.90^{\mathrm{ab}}$ & $1.85^{\mathrm{ab}}$ & $2.13^{\mathrm{a}}$ & 0.14 \\
\hline Albumin:Globulin ratio & $1.55^{\mathrm{a}}$ & $1.03^{\mathrm{b}}$ & $0.97^{\mathrm{b}}$ & $1.10^{\mathrm{b}}$ & $0.88^{\mathrm{b}}$ & $0.80^{\mathrm{b}}$ & 0.14 \\
\hline Aspartate amino transferase $\mu \mathrm{L}$ & 257.83 & 222.00 & 246.67 & 252.33 & 257.67 & 247.00 & 13.73 \\
\hline Alanine amino transferase $\mu \mathrm{L}$ & 31.67 & 32.33 & 31.83 & 36.17 & 34.50 & 33.83 & 2.37 \\
\hline Alkaline Phosphatase $\mu \mathrm{L}$ & $74.00^{\mathrm{a}}$ & $61.83^{\mathrm{b}}$ & $66.50^{\mathrm{ab}}$ & $69.67^{\mathrm{ab}}$ & $71.00^{\mathrm{ab}}$ & $62.50^{\mathrm{b}}$ & 3.52 \\
\hline Serum urea nitrogen $(\mathrm{mg} / \mathrm{dL})$ & 1.20 & 1.23 & 1.12 & 1.12 & 1.20 & 1.12 & 0.06 \\
\hline Creatinine $(\mathrm{mg} / \mathrm{dL})$ & 1.02 & 1.07 & 1.10 & 1.02 & 1.05 & 1.10 & 0.06 \\
\hline
\end{tabular}

Note. *Means no unit; $\quad{ }^{a b c d e}$ :Means in the same row with different superscript differ $\quad$ ed significantly $(\mathrm{P}<0.05)$.

TME 419: Cassava grits from cassava varieties TME 419 SEM: Standard Error of Mean

TMS 01/1371: Cassava grits from cassava varieties TMS 01/1371

\section{Discussion}

The observed higher intake of feed in birds fed two varieties of cassava grits compared with the control may be due to increased acceptability of the diets as earlier documented (Tewe, 1983; Onyimoyi and Ugwu, 2007; Abu et al., 2015) or possibly, the type of cassava products and varieties used. Okeudo et al. (2005) reported a lower daily feed intake of 117.57-131.43g in 
Performance, serum biochemical indices and crude protein utilisation by broiler chickens fed two varieties of cassava grits

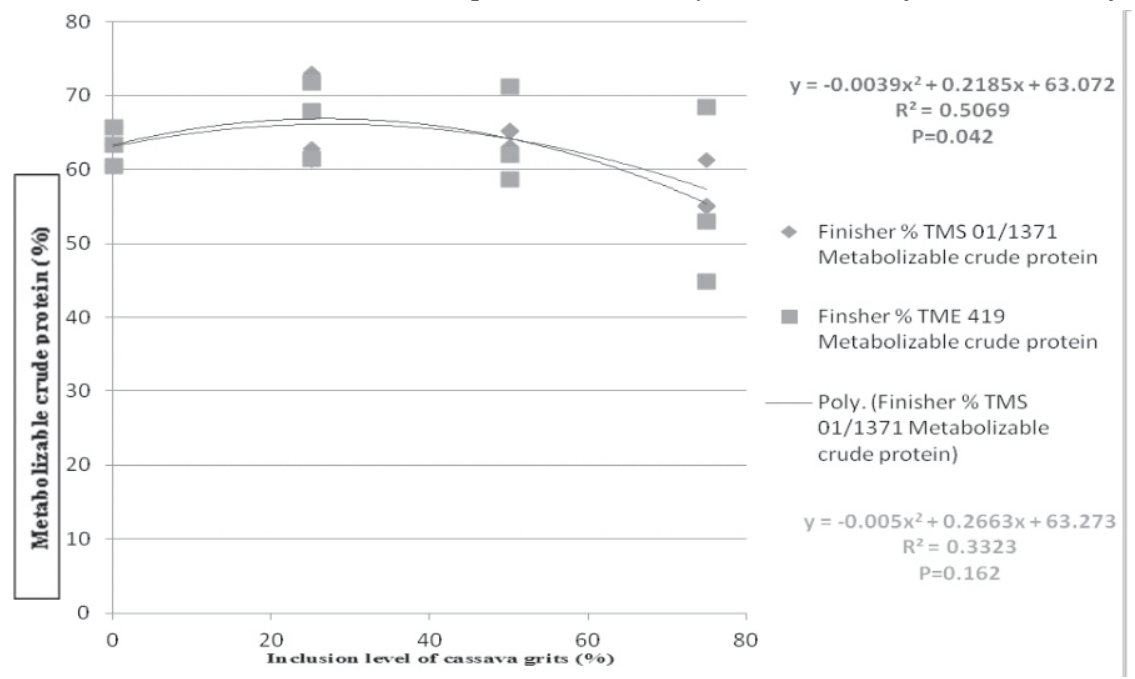

Figure 1: Relationships between metabolizable crude protein and dietary cassava grits inclusion levels for finisher broiler chickens

broilers fed cassava based diets compared with observed range of $139.80-164.62 \mathrm{~g}$ this study. The notable difference could be because of the differences in the age at which test diets were introduced to the birds. In the present case, Arbor Acre broiler strains used were fed test materials from one day old.

The daily weight gain of birds increased with higher inclusion of cassava grits from both varieties of cassava, this may be due to low cyanide level in the cassava grits as high cyanide levels have been demonstrated to reduce performance of monogastrics on cassava-based rations (Tewe, 1982; 1984). The highest weight gain $(69.56 \mathrm{~g})$ was observed in birds on diet 7 which indicated a better utilization of feed by birds for weight gain compared with those diet 1 (control) with daily weight gain of $62.71 \mathrm{~g}$. This observation negated the earlier affirmation of Tewe (1983) on reported reduction in weight gain in finishers' fed increased dietary levels of cassava peels. This difference may also be ascribed to varying cassava products in the ration.

The FCR was higher at lower inclusion level of cassava grits and lower with increased inclusion levels in the broiler diet demonstrating a better utilization of cassava grits from TME 419 at $75 \%$ inclusion level which was contrary to the report of Abu et al. (2015) that FCR of diets based on cassava peel and leaf meal were poor compared with maize based diets. Similar FCR was recorded for birds on control (2.63) and 75\% TMS 01/1371 (2.65) cassava grits.

The MCP of birds fed cassava grits based diets decreased with increased inclusion of cassava grits in the diets. The MCP was however, similar for birds at both 25 and $50 \%$ inclusion levels with the control. It was only at $75 \%$ of both varieties that MCP was lower compared with the control. This observed trend was attributed to increased bulkiness of the diets as earlier posited (Sobayo et al., 2012). Bulkiness will obviously reduce transit time, lower period of enzyme substrate interaction and decrease net crude protein digestibility which may eventually alter utilization of protein. Tewe and Egbunike (1992) opined that methionine is required in the 
Ogunwole, Abayomi, Oladimeji, Olumide, Lawal, Idowu, Mosuro, Kulakow, Iluebbey and Tewe

detoxification of cyanide enzyme rhodanese which could limit the amino acid balance of the diets leading to reduced protein utilization.

The serum total protein of birds were similar and this conform to the findings of Abdel-Fattah et al. (2008) in Hubbard broiler chicks fed different organic acids but higher than the serum total protein of birds fed hydrolyzed cassava peels by Adeyemo and Sani (2013). The difference in total protein obtained in this study and that of Adeyemo and Sani (2013) could be attributed to groundnut cake employed as a source of protein in their study. Groundnut cake, though contained similar crude protein with soybean meal is however, more deficient in methionine and lysine (Adeniji, 2008; Davies and Ezenwa, 2010).

The SUN, albumin, globulin and creatinine are measure of adequacy of protein quality, quantity and degree of protein utilization (Okorie et al., 2011). Elevated globulin levels are mostly due to production of antibodies to fight infections (Agboola et al., 2013). Serum albumin, globulin and $\mathrm{A} / \mathrm{G}$ ratio recorded were similar and conformed with early reports (AbdelFattah, 2008; Ogunwole et al., 2014) indicating that cassava grits based diets from cassava varieties TME 419 and TMS 01/1371 compared favourable with maize based diets in broiler production without compromising the immune system.

There were no significant differences in the AST and ALT of birds fed the cassava grits based diet and the control. The AST catalyses the interconversion of aspartate and $\alpha$-ketoglutarate to oxaloacetate and glutamate, while ALT catalyses the interconversion of glutamate and pyruvate to $\alpha$-ketoglutarate and alanine. The observed similarities in ALT could be further espoused by report of Fernandez et al. (1994) that ALT in biochemical diagnosis is limited in drawing conclusion on birds. Fernandez et al. (1994) relied on evidence from researches and documented inferences (Brugere-Picoux et al., 1987; Campbell and Coles, 1989) that sera AST could be of hepatic or muscular origin, while ALT synthesis was not exclusive to the liver.

The ALP is used to detect bone and liver health. Increase in serum ALP level has been attributed to metabolic changes in the liver developed during administration of toxin, cirrhosis of the liver and hepatitis as well as liver cancer (Mansour et al., 2002; Martin, 2011; Elagib et al., 2012). The lower $(\mathrm{P}<0.05)$ ALP in birds on $50 \%$ cassava grit meant that fed cassava grit did not elicit any toxic effect within the liver parenchyma of birds.

The SUN and creatinine are the simplest way to measure renal function (Kamal, 2014), they depend on the quality and quantity of protein supply (Iyayi and Tewe, 1998). SUN of birds on cassava grits based diets was similar to the control. This suggests similar utilization and absorption of protein in the diets and test materials. Creatinine is a chemical waste molecule that is generated from muscle metabolism (Polat et al., 2011), which is produced at a fairly constant rate by the body depending on muscle mass (Yuegang et al., 2008 and Aguihe et al., 2014). The kidneys maintain the blood creatinine in a normal range. The lower values in the experimental broiler finisher serum revealed inconsequential $(\mathrm{P}>0.05)$ muscular wastage. Similar trend was obtained by Polat (2011).

The relationships between metabolizable crude protein and dietary cassava grit inclusion levels for finisher broiler chickens are shown in Figure 1 and represented by regression equations:

$$
\begin{gathered}
\mathrm{y}=-0.0039 \mathrm{x}^{2}+0.2185 \mathrm{x}+63.072 \\
\left(\mathrm{R}^{2}=0.5069 ; \mathrm{P}=0.042\right) \ldots \ldots \ldots \ldots \ldots \ldots \ldots \ldots \ldots \ldots
\end{gathered}
$$


Performance, serum biochemical indices and crude protein utilisation by broiler chickens fed two varieties of cassava grits

$\mathrm{y}=-0.005 \mathrm{x}^{2}+0.2663 \mathrm{x}+63.273$

$\left(\mathrm{R}^{2}=0.3323 ; \mathrm{P}=0.162\right)$.

Equation 1 revealed significantly reduced $(\mathrm{P}<0.05)$ MCP with increased TMS $01 / 1371$ cassava inclusion levels. In equation 2, the reduction in MCP with increased inclusion levels of TME 419 was not significantly different $(\mathrm{P}>0.05)$.

\section{Conclusion}

Replacement of maize with cassava grit from TME 419 and TMS 01/1371 in broiler chicken ration had no deleterious effect on broiler finisher birds. Increased dietary TME 419 and TMS 01/1371 cassava grits lowered metabolizable crude protein without undermining weight gained and feed conversion ratio of broiler finisher birds. Reduction in metabolizable crude protein was much more pronounced in broiler chicken fed TMS 01/1371.

\section{Acknowledgement}

Authors hereby appreciate the contributions of Amo Farms Siebrier Hatchery, Awe, Oyo State, Nigeria for the free donation of quality day old chicks for this study. Also, we thank the entire Staff and Management of IITA, Ibadan for assisting this research with two varieties of cassava.

\section{References}

Abdel-Fattah, S. A., El-Sanhoury, M. H., El-Mednay, N. M. and AbdelAzeem, F. 2008. Thyroid activity, some blood constituents, organs morphology and performance of broiler chicks fed supplemental organic acids. International Journal of Poultry Science 7 (3): 215-222

Abu, O. A., Olaleru, I. F., Oke, T. D., Adepegba,V. A. and Usman, B.
2015. Performance of broiler chicken fed diets containing cassava peel and leaf meals as replacements for maize and soya bean meal. International Journal of Science and Technology, 4 (4), 169-173

Adeleye, O. O., Ologhobo, A. D. and Oje-Adetule, B. T. 2016. Influence of carbohydrate source on digesta kinetics and post prandial glucose responses of broiler chicks. Livestock Science, 188:37-42.

Adeniji, A. A. 2008. Replacement Value of soyabean Meal with Groundnut Cake with or Without Fishmeal Supplementation in the diets of Pullet Chicks. Journal of Applied Sciences Research, 4(10):12491252.

Adeyemo, I. A. and Sani, A. 2013. Haematological parametres and serum biochemical indices of broiler chickens fed Aspergillus niger hydrolyzed cassava peel meal based diet. IJRRAS 15 (3) $\begin{array}{lllll}J & n e & 2 & 0 & 1\end{array}$ www.arpapress.com/Volumes/Vol 15Issue3/IJRRAS_15_3_24.pdf

Agboola, A. F., Ajayi, $\bar{H}$. I. Ogunbode, S. M., Majolagbe, O. H., Adenekan, O. O., Oguntuyo, C. T. and Opaleye, R. O. 2013. Serum biochemistry and haematological indices of broiler chickens fed graded levels of frog (Rana esculata) meal as replacement to fish meal. International Journal of Agriculture and Biosciences. 2(5): 260-265.

Aguihe, P. C., Kehinde, A. S., Fatokun, B. O., Omotugba, S. $K$ and Ashifat, A. A. 2014. Effect of 
Ogunwole, Abayomi, Oladimeji, Olumide, Lawal, Idowu, Mosuro, Kulakow, Iluebbey and Tewe

enzyme supplementation on ha ematology and serum biochemistry of broiler finishers fed cassava peel meal based diets. Trop. Anim. Prod. Invest. 17 (1): 47-51 $\mathrm{R}$ e $\mathrm{t} \mathrm{r}$ i e $\mathrm{v}$ e d f $\mathrm{r}$ o $\mathrm{m}$ http://animalsci.agric.ui.edu.ng/TAP I/index.php/tapijournal/index

Anton, A. A., Flucher, R. G. and Arntfield, S. D. 2009. Physical and nutritional impact of fortification of corn starch-based extruded snacks with common bean (Phaseolus vulgaris L.) flour: Effects of bean addition and extrusion cooking. Food Chemistry. 134 (1):149-154.

Apata, D. F., Joseph, J. K. and Adeoye, E. O. 1999. Performance, blood composition and carcass quality attributes of rabbits fed dietary levels of cassava and yam wastes. Nigerian Journal of Pure and Applied Science, 14: 768-792

Brugere-Picoux, J., Brugere, H., Basset, I., Sayad, N., Vaast, J. and Michaux, J.-M. 1987. Biochimie clinique en pathologie aviaire. Intérêt et limites des dosages enzymatiques chez la poule. Recuel Médicine Vétérinari, 163: 1091-1099.

Campbell, T. W. and Coles, E. H. 1989. Patología Clinica de Aves. In: Diagnóstico y Patología Veterinaria, 4th edn, pp. 285-308. (México, Editorial Interamericana).

Davies, O. A and Ezenwa N. C. 2008. Groundnut Cake as alternative protein source in the diet of Clarias Gariepinus Fry. International Journal of Science and Nature. 1(1):73-76

Elagib, H. A. A., Nabiela, E. M., Abbass S. A., Ginawi, T. A. N. 2012. Effect of Natural Spices on Plasma Proteins in Broiler Chicks. Journal of Nutrition
Food Science, 2:152. doi:10.4172/2155-9600.1000152

Fajimi, A. O., Babatunde, G. M., Ogunlana, F. F. and Oyejide, A. 1993. Comparative utilization of rubber seed oil and palm oil by broilers in Humid Tropical Environment. Animal Feed Science and Technology, 43:177-178.

Ferket, P. R. and Gernat, A. G. 2006. Factors that affect feed intake of meat birds: A review. Int. Journal of Poultry Science, 5: 905-911.

Fernandez, A., Verde, M. T., Gascon, M., Ramos, J., Gomez, J., Luco, D. F. and Chavez, G. 1994. Variations of clinical biochemical parameters of laying hens and broiler chickens fed aflatoxin-eontaining feed. Avian Pathology, 23(1): 37-47.

Firman J. D. and Boling, S. D. 1998. Ideal protein in turkeys. Journal of Poultry Science, 77:105-110.

IITA. 2011. New vitamin A-fortified cassava released in Nigeria, set to improve health of millions. IITA News of December 12, 2011.

Iyayi, E. A. and Tewe, O. O. 1998. Serum total protein, urea and creatinine levels as indices of quality of cassava diets for pigs. Tropical Vet., 36: 5967.

Kamal, A. 2014. Estimation of blood urea (BUN) and serum creatinine level in patients of renal disorder. Indian Journal of Fundamental and Applied Life Sciences, 4 (4):199-202. ISSN: 2231-6345 (Online)

Mansour, H. A., Newairy, A. S., Yousef, M. I. and Sheweita, S. A. 2002. Biochemical study on the effects of some Egyptian herbs in alloxaninduced diabetic rats. Toxicology, 170: 221-228.

Martin, P. 2011. Approach to the patient 
Performance, serum biochemical indices and crude protein utilisation by broiler chickens fed two varieties of cassava grits

with liver disease. In Goldman L. Schafer A. I., Edns Cecil Medicine. $24^{\text {th }}$ ed. Philadelphia, Pa: Saunders Elsevier: Chapter 148.

Ngiki, Y. U., Igwebuike, J. U., Moruppa, S. M. 2014. Effects of Replacing Maize with Cassava Root-Leaf Meal Mixture on the Performance of Broiler Chickens. International Journal of Science and Technology $3(6)$.

Ofuya, C. O. and Obilor, S. N. 1993. The suitability of fermented cassava peel as poultry feedstuff. Bioresource Technology, 44 (2): 101-104

Ogunwole, O. A., A. B. Omojola, A. P. Sajo and Majekodunmi B. C. 2014. Performance, hematology and serum biochemical indices of broiler chickens fed toasted sesame seed (sesamum indicum, linn) meal baseddiets. American Journal of Experimental Agriculture 4(11): 1458-1470.

Ogunwole, O. A., Lawal, H. O., Idowu, A. I., Oladimeji, S. O., Abayomi, F. D., and Tewe, $\boldsymbol{O}$. O. 2016a. Carcass characteristics, proximate composition and residual retinol in meat of broiler chickens fed $\beta$ carotene cassava (Manihot esculenta crantz)grits based diets. J. Anim. Prod. Res. 28(2):102-117102

Ogunwole, O. A., Idowu, A. I., Lawal, H. O., Oladimeji, S. O., Abayomi, F. D., Mosuro, A. O. and Tewe, O. O. 2016b. Calcium and phosphorus utilization by broiler chickens fed carotene bio-fortified cassava (Manihot esculenta Crantz) grits $\mathrm{b}$ a $\mathrm{s}$ e d $\mathrm{d} \mathrm{i}$ e $\mathrm{t} \mathrm{s}$. I $b$ a $d a n$ Journal of Agricultural Research (Accepted)

Okeudo, N. J., Eboh, K. V., Ndidi, V., Izugboekwe and Akanno, E. C.
2005. Growth rate, carcass characteristics and organoleptic quality of broiler fed graded levels of palm kernel cake. International Journal of Poultry Science, 4 (5): 330-333. ISSN 1682-8356.

Okorie, K. C., Nkwocha, G. A. and Ndubuisi, E. C. 2011. Implications of feeding varying dietary levels of cassava leaf meal on finisher broilers: performance, carcass haematological and serological profiles. Global Research Journal of Science, 1: 58 66, ISBN:2276-8300.

Okudoh, V., C. Trois and Workneh, T. 2014. The potential of cassava biomass as a feedstock for sustainable biogas production in South Africa. Journal of Energy and Power Engineering, 8:836-843

Onyimoyi, A. E. and Ugwu, S. O. C. 2007. Bioeconomic indices of broiler chicks fed varing ratios of cassava peel/bovine blood. Faisalabad, Pakistan: Asian Network for Scientific Information, 6:318-321.

Peter, T., Biamonte, G. T. and Doumas, B. T. 1982. Protein (total protein) in serum, urine and cerebrospinal fluid; albumin in serum. In: selected methods of clinical chemistry, Vol. 9 (W.R. Faulkner and S. Meites, Eds). Washington, DC. American Association for Clinical Chemistry.

Polat, U., Yesilbag, D. and Eren, M. 2011. Serum Biochemical Profile of Broiler Chickens Fed Diets Containing Rosemary and Rosemary Volatile Oil. Journal Biology Environmental Science, 5(13): 23-30

Reinhold, J. G. 1953. Standard method of clinical chemistry, M. Reiner, ed. 
Ogunwole, Abayomi, Oladimeji, Olumide, Lawal, Idowu, Mosuro, Kulakow, Iluebbey and Tewe

Volume 188, Academic Press.

Reitman, S. and Frankel, S. 1957. Glutamic - pyruvate transaminase assay by colorimetric method. American Journal of Clinical Pathology, 28: 56.

Salami, R. I. and Odunsi, A. A. 2003. Evaluation of processed cassava peel meals as substitutes for maize in diets of layers. International Journal of Poultry Science 2(2): 112-116. Asian Network for Scientific Information.

SAS. 2002. SAS language: Reference (Version 6, 1st ed.). SAS Institute Inc., Cary, North Carolina, USA.

Sobayo, R. A., Oso, A. O. Adeyemi, O. A. Fafiolu, A. O., Jegede, A. V. Idowu, O. M. O. Dairo, O U. Iyerimah, R. B. Ayoola, O. A. and Awosanya, R. A. 2012. Changes in growth, digestibility and gut anatomy by broilers fed diets containing ethanoltreated castor oil seed (Ricinus communis L.) meal. Revista Científica UDO Agrícola 12 (3): 660667.

Tewe, O. O. 1982. Protein supplementation of cassava diets for growing pigs, effect on performance, nutrient utilization and cyanide metabolism. Nutrition Reports International 25(3):451-462.

Tewe, O. 1983. Thyroid cassava toxicity in animals. Pages 114-118 in Cassava toxicity end thyroid: research and public health issues. Proceedings, International Workshop on Cassava Toxicity, edited by F. Delange and R Ahluwalia, 31 May-2 June 1982, Ottawa, Canada. IDRC-207e: Ottawa.

Tewe, O. O. 1984. Cyanogenic glucoside, protein interaction in cassava peel based rations: effect on some hematological parameters in growing pigs. Nutrition Reports International 30(2):425-431.

Tewe, O. O. 1997. Sustainability and development paradigm from Nigeria's livestock industry. Inaugural Lecture delivered on behalf of Faculty of Agriculture and Forestry, University of Ibadan, Pp 50.

Tewe, O. O. 2005. Tewe Grits, Federal Repbublic of Nigeria, Patents and Decree 1970 (1970 No.60), Patent No RP:16198.

Tewe, O. O. and Egbunike, G. N. 1992. Utilization of cassava in non ruminant livestock feeds. Cassava as livestock feed in Africa. Proceedings of the IITA/ILCA/University of Ibadan workshop on the potential utilization of cassava as livestock feed in Africa. Nigeria, 28-38.

Toro, G. and Ackermann, P. G. 1975. Practical clinical chemistry. Little, Brown and company, Boston.

Weurding, R. E., Veldman, A., Veen, W. A. G. van der Aar, P. J. and Verstegen, M. W. A. 2001. In vitro starch digestion correlates well with rate and extent of starch digestion in broiler chickens. Journal of Nutrition, 131:2336-2342.

Weurding, R. E., Enting, H. and Verstegen, M. W. A. 2003. The relation between starch digestion rate and amino acid level for broiler chickens. Poultry Science, 82:279-284.

Yuegang, Z., Chengjum, W. and Chengjun, T. 2008. Simultaneous determination of creatinine and uric acid in human urine by high performance liquid chromatography. Analytic Science 24: 1589-1592.

Received: $25^{\text {th }}$ August, 2016 Accepted: $4^{\text {th }}$ March, 2017 